\title{
Compatible solutes in different organs of mangrove trees
}

\author{
M. Popp ${ }^{1}$ and J. Polania ${ }^{2}$ \\ 1 Institut für Angewandte Botanik, Universität Münster, F.R.G., and \\ 2 Institut für Pflanzenphysiologie, Universität Wien, Austria
}

\section{Introduction}

According to Brown and Simpson (1972), a compatible solute may be "loosely defined as one which, at high concentration, allows an enzyme to function effectively". This definition was developed from work on sugar-tolerant yeast and was later adapted to halophytes, which also need osmolytes in the cytoplasm to assure the intracellular osmotic adjustment between vacuole (rich in $\mathrm{NaCl}$ ) and cytoplasm (poor in NaCl) (Stewart et al., 1979).

Earlier work on mangroves has revealed that these halophytic trees stored high concentrations of either mannitol, pinitol, quebrachitol, proline or glycine betaine in their leaves (Popp et al., 1985). In the meantime, further work on the Rhizophoraceae showed that the cyclitol formerly identified as pinitol was 10-O-methylmuco-inositol (Richter, Thonke and Popp, manuscript in preparation).

The present study was undertaken to elucidate the role of these organic solutes in various mangrove species by investigating their distribution in different plant organs and their reaction to long- and short-term variations in salinity.

\section{Materials and Methods}

Mangrove material was collected at the Dampier Archipelago (Western Australia) during March/April 1984. Sample preparation and analytical procedures were those described by Popp et al. (1985). Culture experiments were carried out in a glass-house in Vienna with additional light and a temperature regime of $28-30^{\circ} \mathrm{C}$ during the day and $20^{\circ} \mathrm{C}$ at night. Plants were grown on a substrate of volcanic beads and supplied with appropriate concentrations of seawater prepared from commercialIy available sea-salt for aquariums. $1 \mathrm{mM}$ $\mathrm{NH}_{4} \mathrm{NO}_{3}, 1 \mathrm{mM} \mathrm{NH}{ }_{4} \mathrm{Cl}, 0.1 \mathrm{mM} \mathrm{KH_{2 }} \mathrm{PO}_{4}$ and $0.05 \mathrm{mM}$ FeEDTA were added to the seawater. The solutions were changed every 2 wk. Whole plants were harvested and divided into the different organs. Roots were subjected to a standardized washing-procedure.

\section{Results}

For osmotic considerations data in Table 1 are given in $\mathrm{mol} \cdot \mathrm{m}^{-3}$ plant water. The concentrations of $\mathrm{Na}^{+}$and $\mathrm{Cl}^{-}$in seawater were 459 and $535 \mathrm{~mol} \cdot \mathrm{m}^{-3}$, respectively, and were very often in the same range in the different plant organs (Table I). Where twigs could be separated 
Table I. Compatible solutes, $\mathrm{Cl}^{-}, \mathrm{Na}^{+}$and $\mathrm{K}+$ concentrations in $\mathrm{mol} \cdot \mathrm{m}^{-3}$ plant water in different parts of mangrove trees collected at the Dampier Archipelago ( $\mathrm{nd}=$ not determined).

\begin{tabular}{|c|c|c|c|c|c|}
\hline Species/plant part & $\mathrm{Cr}$ & $\mathrm{Na}^{+}$ & $K^{+}$ & \multicolumn{2}{|c|}{ Solute } \\
\hline \multicolumn{6}{|l|}{ Aegiceras corniculatum } \\
\hline very young leaves & 336 & 359 & 144 & 186 & mannitol \\
\hline old leaves & 487 & 457 & 175 & 248 & mannitol \\
\hline old twigs, bark & nd & 534 & 234 & 123 & mannitol \\
\hline old twigs, wood & nd & 268 & 146 & 175 & mannitol \\
\hline \multicolumn{6}{|l|}{ Aegialitis annulata } \\
\hline young leaves & 616 & 485 & 99 & 49 & pinitol \\
\hline old leaves & 446 & 367 & 93 & 53 & pinitol \\
\hline young twigs, bark & 761 & 917 & 95 & 18 & pinitol \\
\hline young twigs, wood & 620 & 375 & 86 & 30 & pinitol \\
\hline \multicolumn{6}{|l|}{ Rhizophora stylosa } \\
\hline young twigs, bark & 800 & 656 & 73 & 99 & 1D-O-methyl-muco-inositol \\
\hline young twigs, wood & 385 & 362 & 104 & 186 & 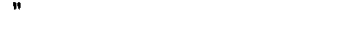 \\
\hline stilt roots, outer layer & 745 & 521 & 101 & 283 & " \\
\hline stilt roots, inner layer & 472 & 376 & 56 & 277 & $"$ \\
\hline \multicolumn{6}{|l|}{ Avicennia marina } \\
\hline very young leaves & 566 & 539 & 120 & 238 & glycine betaine \\
\hline old leaves & 763 & 889 & 148 & 145 & \\
\hline twigs, $\varnothing 1.0 \mathrm{~cm}$ & 519 & 441 & 159 & 238 & glycine betaine \\
\hline twigs, $\varnothing 1.5 \mathrm{~cm}$ & 454 & 435 & 133 & 213 & \\
\hline
\end{tabular}

Table II. Proline content ( $\mu \mathrm{mol} \cdot \mathrm{g}^{-1} \mathrm{dry}$ weight) in different organs of $A$. annulata, cultivated in $50 \%$ seawater and transferred into 150 and $0 \%$ seawater for $8 \mathrm{~d}$.

\begin{tabular}{lccl}
\hline Organ & $50 \%$ seawater & After 8 d in $0 \%$ seawater & After 8 d in 150\% seawater \\
\hline Roots & $3.32 \pm 1.70$ & $1.66 \pm 0.46$ & $11.93 \pm 3.81$ \\
Stems & $15.48 \pm 7.42$ & $9.68 \pm 2.24$ & $36.70 \pm 8.43$ \\
Leaves & $10.73 \pm 4.85$ & $16.26 \pm 7.45$ & $12.93 \pm 9.17$ \\
\hline
\end{tabular}

into bark and wood, $\mathrm{Na}^{+}$and $\mathrm{Cl}^{-}$ accumulated to a higher extent in the bark, while the opposite was true for the organic solutes.

In addition to the 4 species listed in Table 1, we know from Rhizophora mangle, Bruguiera exaristata, Ceriops tagal and Laguncularia racemosa that the organic solutes present in the leaves also accumulated in all other plant organs.

Compared to the other species, the pinitol content in $A$. annulata was low, but this species contained 2 additional organic solutes: chiro-inositol $\left(11-25 \mathrm{~mol} \cdot \mathrm{m}^{-3}\right)$ and proline $\left(0.4-5.0 \mathrm{~mol} \cdot \mathrm{m}^{-3}\right)$, which were again present in all different plant parts.

In a long-term experiment with $A$. corniculatum, we tested the influence of salinity on the mannitol concentration in the leaves. Plants were kept for $1 \mathrm{yr}$ at either 10 or $100 \%$ seawater, leaves of approximately the same age were harvested from 4 or 5 different plants, respectively. The mannitol content of $10 \%$ 
seawater plants was $41 \pm 14.8 \quad(n=4)$ $\mathrm{mol} \cdot \mathrm{m}^{-3}$ plant water, while in $100 \%$ seawater plants it was $79 \pm 7.0 \quad(n=5)$ $\mathrm{mol} \cdot \mathrm{m}^{-3}$ plant water.

The effects in the short-term experiment with $A$. annulata were not as pronounced. However, the up-shock $(8 \mathrm{~d}$ in $150 \%$ seawater) treatment showed a clear increase in proline concentrations in roots and stems (Table II).

\section{Discussion and Conclusion}

Our results are in agreement with those obtained for herbaceous halophytes in that one and the same organic solute was present in all organs of a given plant (Briens and Larher, 1982).

Acyclic polyols, such as sorbitol and mannitol, are known to play an important role in the carbohydrate metabolism of trees other than mangroves (Loescher, 1987). Our results suggest that mannitol also functioned in the overall osmotic adjustment of $A$. corniculatum. Further experiments are in progress to determine if cyclic polyols (pinitol, 10-O-methylmuco-inositol) behave in the same way. Proline accumulation in $A$. annulata was similar to that observed for herbaceous halophytes (Stewart et al., 1979). The reaction to changes in salinity and the rather low concentration of this solute imply a role different from that of the polyols. It might be postulated that proline is more restricted to the cytoplasm, while the polyols also accumulate in vacuoles.

\section{Acknowledgments}

This work was supported by the Austrian Research Fund (project no. 5784). The kind and skilful technical assistance of $G$. Hermann and I. Lechner is gratefully acknowledged.

\section{References}

Briens M. \& Larher F. (1982) Osmoregulation in halophytic higher plants: a comparative study of soluble carbohydrates, polyols, betaines and free proline. Plant Cell Environ. 5, 287-292

Brown A.D. \& Simpson J.R. (1972) Water relations of sugar-tolerant yeasts: the role of intracellular polyols. J. Gen. Microbiol. 72, 589-591

Lœscher W.H. (1987) Physiology and metabolism of sugar alcohols in higher plants. Physiol. Plant. 70, 553-557

Popp M., Larher F. \& Weigel P. (1985) Osmotic adaptation in Australian mangroves. Vegetatio 61, 247-253

Stewart G.R., Larher F., Ahmad I. \& Lee J.A. (1979) Nitrogen metabolism and salt tolerance in higher plant halophytes. Symp. Ecological Processes in Coastal Environments (Jefferies R.L. \& Davy A.J., eds.), Blackwell Sci. Publ., London, pp. 211-227 